8. Voitkevitch, S. A. (2000). Efirni masla, arimatizatiri, konservanti. Moscow: Drofa, 67.

9. Zharkova, C. O., Demchenko, A. C., Podgaina, M. V., Khomenko, V. M. (2013). Ocinka tendencij spozhivannj protipukhlinnikh preparativ ta zakhvoruvanosti na rak shlunka v Ukraini ta cviti. Pharmacevtichiy zhurnal, 3, 9-15.
10. Statystyka onkologichnyh zahvorjuvan' v Ukrai'ni. Available at: http://diapharma.ua/articles/statistikaonkologichnih-zahvoryuvan-v-ukrayini

11. Osnovni prychyny j poshyrenist' zlojakisnyh puhlyn. Available at: http://www.cancer.ic.ck.ua/ u_index_3_1.htm

Рекомендовано до публікації д-р біол. наук Шейко В. I. Дата надходження рукопису 23.01.2015

Полковенко Ольга Володимирівна, кандидат біологічних наук, доцент, кафедра анатомії і фізіології людини, Інститут людини Київського університету імені Бориса Грінченка, вул. Бульварно-Кудрявська, 18/2, м. Київ, Україна, 04053

E-mail: tpluso@ukr.net

УДК 612.015.2:591.05:599.323.4:176

DOI: $10.15587 / 2313-8416.2015 .37406$

\title{
ВПЛИВ ІМУНОМОДУЛЯТОРІВ ПРИРОДНОГО ПОХОДЖЕННЯ НА ПОКАЗНИКИ КЛІТИННОГО ІМУНІТЕТУ КРОВІ КРОЛИКІВ ЗА УМОВ СТРЕСУ
}

\author{
(C) С. С. Грабовський, О. С. Грабовська
}

Досліджували T- і В-лімфоцити кроликів при використанні імуномодуляторів за умов стресу. Введення імуномодуляторів має стимулювальний вплив на кількість $T$ - $і$ B-лімфоцитів $і$ функиіональну активність $T$ - $і$ В-клітинного імунітету в крові кроликів перед їх забоєм. Отримані результати можуть бути використані для підвищення резистентності організму, корекції та зняття впливу передзабійного стресу тварин.

Ключові слова: кролики, передзабійний стрес, екстракти селезінки, T- і В-лімфоцити

Aim. The article is devoted to the researching of $T$ - and B-lymphocytes relative amount in the rabbits blood after using of plant and animal origin immunomodulators under stress.

Methods. The relative amount of $T$ - and B-lymphocytes and its some populations in the reaction of spontaneous rosetting with the ram erythrocytes in the blood was determined. Thus, the differentiated count of rosetting lymphocyte with the different functional activity degree was conducted. The spleen extracts added to the rabbits feed by aerosol introduction method.

Results. T- and B-lymphocytes amount and functional activity $T$ - and B-cell immunity was stimulated after additional supplementary to rabbits diet of experimental group natural origin immunomodulators. Spleen extract polyamines as the immunomodulators and antistressors most effectively influenced on some $T$-and B-cell immunity indices before slaughter: amount of T-(Th-0) and B-(3-5)lymphocytes were decreased.

Conclusions. The results which obtained in experiment can to use in researches of cell immunity indices on farm animals for organism resistance increasing and correction their pre-slaughter stress.

Keywords: rabbits, pre-slaughter stress, spleen extracts, T- and B-lymphocytes

\section{1. Вступ}

Функціонуючою основою імунної системи $\epsilon$ складний комплекс імунокомпетентних клітин (Т-, Влімфоцити, макрофаги). На відміну від В-лімфоцитів, здатних розпізнавати антигени в розчині і зв'язувати білкові, полісахаридні і ліпопротеїдні розчинні антигени, Т-лімфоцити здатні розрізняти тільки короткі пептидні фрагменти білкових антигенів [1]. У попередніх дослідженнях нами встановлено вплив передзабійного стресу на клітинний імунітет та рівень кортизолу у крові щурів [2].

\section{2. Постановка проблеми}

У літературі недостатньо висвітлені питання про вплив передзабійного стану тварин на окремі показники імунітету. Слід пам'ятати, що перед забоєм сільськогосподарських тварин не можна використовувати препарати, які б мали негативний вплив на організм людини після споживання продукції від цих тварин. Саме тому у дослідженнях ми використали біологічно активні речовини природного походження - екстракт селезінки. Метою роботи було встановити чи підвищується резистентність та імунітет у кроликів при одночасному зменшенні передзабійного стресу за використання екстракту селезінки.

\section{3. Літературний огляд}

3 літературних джерел відомо про вплив стресу різного характеру на Т- і В-клітинний імунітет 
[3-8]. У контролі вродженої імунної відповіді у вищих хребетних відіграють важливу роль поліаміни: спермідин, спермін та путресцин. Поліаміни можуть сприяти розвитку відповідної адаптивної імунної реакції $[9,10]$, поглинатися Т- та В-лімфоцитами, регулювати апоптоз В-клітин [11]. Встановлено вищий рівень поліамінів у крові та окремих тканинах курчат-бройлерів, яким до основного раціону вносили екстракт селезінки [12], що дозволило використати цей субстрат як імуномодулятор та з'ясувати його дію ще й як антистресора. Екстраговані поліаміни отримували 3 екстракту селезінки із застосуванням ультразвуку [13].

\section{4. Вплив імуномодуляторів природного походження на показники клітинного імунітету крові кроликів за умов стресу \\ Дослід провели на 10 кроликах породи білий} велетень, яких утримували на стандартному гранульованому комбікормі фермерського господарства Бузького району Львівської області. Для дослідження сформовали дві групи тварин 5-місячного віку (по п'ять у кожній). Як біологічно активні речовини у передзабійний період (за п'ять діб до забою) використовували екстракт селезінки, одержаний із застосуванням ультразвуку (дослід). Екстракти наносили на комбікорм аерозольним методом $\left(70^{\circ}\right.$ спиртовий розчин екстракту селезінки об'ємом 1,4 мл на тварину). Кроликам контрольної групи таким же чином давали до корму $70^{\circ}$ розчин етанолу в аналогічному об'ємі. Утримання, годівлю, догляд та усі маніпуляції з тваринами здійснювали згідно з Свропейською конвенцією «Про захист хребетних тварин, які використовуються для експериментальних і наукових цілей» (Страсбург, 1986 р.) і «Загальних етичних принципів експериментів на тваринах», ухвалених Першим Національним конгресом з біоетики (Київ, 2001). Експерименти проводили 3 дотриманням принципів гуманності, викладених у директиві Свропейської Спільноти [14].

У цільній крові кроликів визначали відносну кількість Т- і В-лімфоцитів та їх окремих популяцій у реакції спонтанного розеткоутворення 3 еритроцитами барана в якості маркерів. За кількістю еритроцитів, адсорбованих одним лімфоцитом, судили про ступінь активності лімфоцитів. Визначали відносну кількість загальних (ТЕ-РУЛ загальні розеткоутворюючі лімфоцити) та активних Т-лімфоцитів (ТА-РУЛ - активні розеткоутворюючі лімфоцити). Для відмивання лімфоцитів використовували забуферений фізіологічний розчин (рН розчину 7,2-7,4 (7,3). Мононуклеарну фракцію клітин виділяли 3 гепаринізованої крові кроликів. Мазки висушували, фіксували метанолом, фарбували 7-10 хв за Романовським-Гімзою. Мікроскопію мазків робили під імерсією при збільшенні 90×7. Лімфоцити за кількістю приєднаних еритроцитів: нульові - не приєднали жодного; малодиференційовані (низькоавідні або клітини з малою щільністю поверхневих рецепторів) - приєднали 3-5 еритроцитів; середньоавідні субпопуляції 6-10 еритроцитів; високодиференційовані (високо- авідні) - «розетки» 3 більше як 10 еритроцитами (М морула).

Визначення відносної кількості теофілінрезистентних лімфоцитів (Т-хелперів, Тh) грунтується на тому, що ці клітини несуть на своїй поверхні рецептори до імуноглобулінів класу М, а Тсупресори - до імуноглобулінів класу G. Хелперні лімфоцити, здатні формувати розетки після їх інкубації 3 теофіліном - це теофілінрезистентні клітини. Кількість теофілінчутливих лімфоцитів (Тсупресорів, Тs) визначали за різницею між кількістю ТЕ-РУЛ та Т-хелперів.

Визначали відносну кількість В-лімфоцитів, метод ідентифікації яких грунтується на наявності у них мембранних імуноглобулінових рецепторів, що забезпечує приєднання до В-лімфоцитів індикаторних клітин, які на своїй поверхні містять комплемент-антиген-комплекс (ЕАС-РУЛ). Як індикаторні клітини використовували еритроцити барана, сенсибілізовані антитілами i комплементом. Для приготування комплемент-антиген-комплексу використовували готову рідку гемолітичну сироватку (титр $1: 1200)$ та готовий сухий комплемент морської свинки [15].

Математичну обробку результатів опрацьовували статистично за допомогою пакету програм Statistica 6.0 i Microsoft Excel for Windows XP. Вірогідність різниць оцінювали за t-критерієм Стьюдента. Результати вважали вірогідними при $\mathrm{P} \leq 0,05$.

Аналізуючи отримані результати досліджень не було встановлено вірогідних різниць у кількості загальних та активних Т-лімфоцитів у крові кроликів як дослідної, так і контрольної груп (табл. 1). Однак, відмічено зменшення кількості недиференційованих лімфоцитів (Th-0) у кроликів дослідної групи на $5,5 \%(\mathrm{P}<0,01)$ порівняно 3 контролем. Встановлено зменшення кількості малодиференційованих лімфоцитів, які приєднали 3-5 еритроцитів. Спостерігалася тенденція до зменшення відсотка Тs у крові кроликів дослідної групи, що може вказувати на збільшення кількості В-клітин та синтез антитіл, але ці дані невірогідні. Кількість В-лімфоцитів вірогідно менша - на $12,5 \%$ ( $<<0,01)$ у крові тварин дослідної групи за рахунок малодиференційованих лімфоцитів, які приєднали 3-5 еритроцитів. 3 цих даних випливає, що внесення екстракту селезінки до корму кроликам дослідної групи має вплив на функціональні властивості Т-лімфоцитів крові, зокрема активує рецепторний апарат клітин.

У модельному експерименті на щурах ми вивчали вплив передзабійного стресу на клітинний імунітет i концентрацію в крові кортизолу стресового гормону. У крові щурів, які отримували екстракт селезінки, була більша кількість Т-лімфоцитів активних, Т-лімфоцитів хелперів «нульових» та вірогідно нижчий рівень кортизолу, що може свідчити про зменшення стресу перед забоєм. Отже, додаткове введення щурам імуномодуляторів природного походження мало стимулювальний вплив на функціональну активність Т- і В-клітинної ланок імунітету [2]. 
У табл. 1 представлені показники клітинного імунітету крові кроликів за умов передзабійного стресу.

Таблиця 1

Кількість Т- і В-лімфоцитів та їх функціональна активність у крові кроликів, \% $(\mathrm{M} \pm \mathrm{m} ; \mathrm{n}=5)$

\begin{tabular}{|c|c|c|}
\hline \multirow{2}{*}{ Показники } & \multicolumn{2}{|c|}{ Група тварин } \\
\cline { 2 - 3 } & Дослідна & Контрольна \\
\hline $\begin{array}{c}\text { Т-загальні } \\
\text { ТЕ-РУЛ), }\end{array}$ & $51,50 \pm 1,73$ & $53,75 \pm 2,22$ \\
\hline $3-5$ & $37,50 \pm 2,08$ & $35,25 \pm 2,22$ \\
\hline $6-10$ & $7,75 \pm 1,26$ & $7,50 \pm 1,29$ \\
\hline М & $3,25 \pm 1,89$ & $3,502 \pm 2,08$ \\
\hline$\%$ & $48,50 \pm 1,73$ & $46,25 \pm 2,22$ \\
\hline $\begin{array}{c}\text { Т-активні } \\
\text { (ТА-РУЛ), }\end{array}$ & $74,00 \pm 2,94$ & $78,00 \pm 1,83$ \\
\hline $3-5$ & $21,50 \pm 3,42$ & $18,75 \pm 3,40$ \\
\hline $6-10$ & $4,50 \pm 1,73$ & $3,00 \pm 1,41$ \\
\hline$\%$ & $26,00 \pm 2,94$ & $22,00 \pm 1,83$ \\
\hline $\begin{array}{c}\text { Т-теофілін- } \\
\text { резистентні (Тh), }\end{array}$ & $72,00 \pm 1,83 * *$ & $76,00 \pm 1,63$ \\
\hline 0 & & $20,75 \pm 1,50$ \\
\hline $3-5$ & $22,25 \pm 2,87$ & $3,00 \pm 1,41$ \\
\hline $6-10$ & $4,75 \pm 0,50$ & $0,25 \pm 0,50$ \\
\hline М & $1,00 \pm 0,82$ & $24,00 \pm 1,63$ \\
\hline$\%$ & $28,00 \pm 1,83 * *$ & $22,25 \pm 0,96$ \\
\hline Т-супресори (Тs) & $20,50 \pm 3,11$ & $53,00 \pm 6,78$ \\
\hline В-РУЛ (ЕАС- & $54,00 \pm 2,94$ & $33,75 \pm 1,50$ \\
\hline РУЛ), 0 & $30,00 \pm 2,16 * *$ \\
\hline $3-5$ & $10,25 \pm 0,96$ & $7,00 \pm 3,46$ \\
\hline $6-10$ & $5,75 \pm 1,26$ & $6,25 \pm 4,50$ \\
\hline М & $45,00 \pm 2,65 * *$ & $50,33 \pm 1,53$ \\
\hline
\end{tabular}

Примітка: статистична вірогідність різниць: ** - $\mathrm{P}<0,01$ порівняно до контролю

Дослідження на щурах та кроликах вказують на те, що біологічно активні речовини екстракту селезінки (поліаміни) підвищують резистентність організму, корегують та нівелюють вплив стресу перед забоєм тварин.

\section{5. Висновки}

Таким чином, встановлено, що як імуномодулятори та антистресори, поліаміни з екстракту селезінки впливають на показники Т- і Вклітинного імунітету в крові кроликів перед їх забоєм. При цьому зменшується кількість Ттеофілінрезистентних ((Th), 0) недиференційованих лімфоцитів та В-РУЛ (3-5) малодиференційованих (низькоавідних або клітин 3 малою щільністю поверхневих рецепторів).

\section{Література}

1. Лаповець, Л. Є. Посібник з лабораторної імунології [Текст] / Л. Є. Лаповець, Б. Д. Луцик, Г. Б. Лебедь. - Львів, 2014. - 292 с.

2. Грабовський, С. С. Вплив імуномодуляторів природного походження на показники клітинного імунітету і рівень кортизолу в крові щурів за умов стресу
[Текст] / С. С. Грабовський // Біологічні Студії. - 2014. T. 8, № 1. - C. 93-102

3. Чернушенко, Е. Ф. Местный иммунитет: диагностика его нарушений и возможности коррекции [Текст] / Е. Ф. Чернушенко // Мистецтво лікування.

2007. - Вип. 7, № 43. - С. 61-67.

4. Groer, M. Reduction of hair glucocorticoid levels in an animal model of post-traumatic stress disorder (PTSD) [Text] / M. Groer, S. Wolfe, C. R. Park // Brain, Behavior, and Immunity. - 2013. - Vol. 68, Issue 32. - P. 20. doi: 10.1016/j.bbi.2013.07.080

5. Кузьменко, О. В. Добові ритми показників імунної системи щурів і радіочутливість [Текст] / О. В. Кузьменко // Експериментальна і клінічна медицина. -2011 . - Вип. 1, № 50. - С. 132-141.

6. Киселёва, Н. М. Стресс и лимфоциты [Текст] / Н. М. Киселёва, Л. Г. Кузьменко, М. М. Нкане Нкоза // Педиатрия. - 2012. - Вып. 91, № 1. - С. 137-143.

7. Marvar, P. J. T lymphocytes and vascular inflamemation contribute to stress-dependent hypertension [Text] / P. J. Marvar, A. Vinh, S. Thabet et al. // Biological psychiatry. - 2012. - Vol. 71, Issue 9. - P. 774-782. doi: 10.1016/j.biopsych.2012.01.017

8. Салига, Н. Т- і В-клітинний імунітет за умов введення L-глутамінової кислоти [Текст] / Н. Салига // Вісник Львівського університету. Серія біологічна. 2012. - Вип. 58. - С. 80-84.

9. Naduge, M. Polyamines in aging and disease [Text] / M. Naduge, C-G. Didac, M. Frank // AGING. - 2011. - Vol. 3, Issue 8. - P. 1-16.

10. Reyes-Becerril, M. Effects of polyamines on cellular innate immune response and the expression of immunerelevant genes in gilthead seabream leucocytes [Text] / M. Reyes-Becerril, F. Ascencio-Valle, D. Tovar-Ramнrez et al. // Fish Shellfish Immunol. - 2010. - Vol. 30 - P. 248254. doi: 10.1016/j.fsi.2010.10.011

11. Nitta, T. Involvement of Polyamines in B Cell Receptor-Mediated Apoptosis: Spermine Functions as a Negative Modulator [Text] / T. Nitta, K. Igarashi, A. Yamashita et al. // Experimental Cell Research. - 2001. - Vol. 265, Issue 1. - P. 174-183. doi: 10.1006/excr.2001.5177

12. Грабовський, С. С. Вміст поліамінів та їх корекція у крові та тканинах курчат-бройлерів за умов стресу [Текст] / С. С. Грабовський // Біологія тварин. 2014. - Том 16, № 2. - С. 18-25.

13. Грабовский, С. С. Экстрагирование биологически активных веществ селезенки с использованием ультразвука [Текст] / С. С. Грабовский // Сборник научных трудов SWorld. Иваново: МАРКОВА А. Д. - 2013. - Т. 49, Вып. 4. - С. 3-6.

14. Official Journal of the European Union L276/33 [Text] / Directive 2010/63/EU of the european parliament and of the council of 22 September 2010 on the protection of animals used for scientific purposes. 86/609/EC. 20.10.2010.

15. Влізло, В. В. Лабораторні методи досліджень у біології, тваринництві та ветеринарній медицині : довідник [Текст] / В. В. Влізло, Р. С. Федорук, І. Б. Ратич та ін.; за ред. В. В. Влізла. - Львів : Сполом, 2012. - 764 с.

\section{References}

1. Lapovecz, L. Ye., Lucyk, B. D., Lebed, G. B. (2014). Manual of Laboratory Immunology, Lviv, 292. [in Ukrainian]

2. Grabovskyi, S. S. (2014). Natural origin immunomodulators influence on cellular immunity indices and cortisol level in rats blood at pre-slaughter stress. Studia Biologica, 8 (1), 93-102. [in Ukrainian]

3. Chernushenko, E. F. (2007). Local immunity: diagnostics of its violations and possibility of correction. Art of treatment, 7(43), 61-67. [in Russian] 
4. Groer, M., Wolfe, S. Park, C. R. (2013). Reduction of hair glucocorticoid levels in an animal model of posttraumatic stress disorder (PTSD) Brain, Behavior, and Immunity, 68 (32), 20. doi: 10.1016/j.bbi.2013.07.080

5. Kuzmenko, O. V. (2011). Daily rhythm of immune system indexes rats and radio sensitivity. Experimental and clinical medicine, 1 (50), 132-141. (in Ukrainian).

6. Kyseleva, N. M., Paediatrics, 91(1), 137-143. [in Russian]

7. Marvar, P. J., Vinh, A., Thabet, S. et al. (2012). T lymphocytes and vascular inflammation contribute to stressdependent hypertension. Biological psychiatry, 71 (9), 774782. doi: 10.1016/j.biopsych.2012.01.017

8. Salyha, N. (2012). T- and B-cells immunity at the condition introduction L-glutamic acid. Visnyk of Lviv Univ. Biology Series, 58, 80-84. [in Ukrainian]

9. Naduge, M., Didac, C-G., Frank, M. (2011). Polyamines in aging and disease. AGING, 3 (8), 1-16.

10. Reyes-Becerril, M., Ascencio-Valle, F., TovarRamurez, D. et al. (2010). Effects of polyamines on cellular innate immune response and the expression of immune-relevant genes in gilthead seabream leucocytes. Fish Shellfish Immunol., 30, 248-254. doi: 10.1016/j.fsi.2010.10.011

11. Nitta, T., Igarashi, K., Yamashita, A. et al. (2001). Involvement of Polyamines in B Cell Receptor-Mediated Apoptosis: Spermine Functions as a Negative Modulator. Experimental Cell Research, 265 (1), 174-183. doi: 10.1006/excr.2001.5177

12. Grabovskyi, S. S. (2014). Polyamines content and its correction in broiler chickens blood and tissues at preslaughter stress. The Animal Biology, 16 (2), 18-25. [in Ukrainian]

13. Grabovskyi, S. S. (2013). Extracting of biologically active substances of spleen with the application an ultrasound. Proceedings SWorld. Ivanovo: Markova A. D., 4 (49), 3-6. [in Russian]

14. Official Journal of the European Union L276/33. Directive 2010/63/EU of the european parliament and of the council of 22 September 2010 on the protection of animals used for scientific purposes. 86/609/EC. 20.10.2010.

15. Vlizlo, V. V., Fedoruk, R. S., Ratych, I. B. et al. (2012). Laboratory methods of investigation in biology, stockbreeding and veterinary : Reference book ; Edited by V. V. Vlizlo. Lviv : SPOLOM, 764. [in Ukrainian]

Рекомендовано до публікації д-р біол. наук, професор Малик О. Г. Дата надходження рукопису 27.01.2015

Грабовський Степан Стефанович, кандидат біологічних наук, кафедра біологічної та загальної хімії, Львівський національний університет ветеринарної медицини та біотехнологій ім. С. 3. Гжицького, вул. Пекарська, 50, м. Львів, Україна, 79010

E-mail: grbss@ukr.net

Грабовська Олександра Степанівна, кандидат біологічних наук, Лабораторія інтелектуальної власності та маркетингу інновацій, Інститут біології тварин НААН, вул. В. Стуса, 38; м. Львів, Україна, 79034

E-mail: alice_grb@ukr.net 